\title{
CONTROL OF ROOT-KNOT NEMATODE (MELOIDOGYNE INCOGNITA) IN TOMATO (SOLANUM LYCOPERSICUM) CROP USING SIAM WEED (CHROMOLAENA ODORATA) COMPOST MANURE
}

\author{
Stephen A. ABOLUSORO ${ }^{1}$, Aruna Olasekan ADEKIYA ${ }^{1 *}$, Charity AREMU ${ }^{1}$, Sunday IGE ${ }^{1}$, \\ Nkechi B. IZUOGU ${ }^{2}$, Patricial F. ABOLUSORO ${ }^{3}$, Avwerosuo ERERE ${ }^{1}$, Samuel OBANIYI ${ }^{1}$ \\ ${ }^{1}$ Landmark University, Omu-Ara, Nigeria \\ ${ }^{2}$ Department of Crop Protection, Faculty of Agriculture, University of Ilorin, Nigeria \\ ${ }^{3}$ Department of Agricultural Education, Kogi State College of Education (Tech.), Egbeda Kabba, Nigeria
}

Received: December 2019; Accepted: April 2020

\begin{abstract}
A field experiment was conducted at Landmark University Omu-Aran, Nigeria from June to November 2017 and repeated at the same time in the year 2018 on a nematode infested soil to evaluate the effects of different amounts of Siam weed compost on the performance of root-knot nematode (RKN) infested tomato. The compost was applied a week before planting as soil amendment at the amount of 0.0, 0.5, 1.5, and $2.0 \mathrm{t} \cdot \mathrm{ha}^{-1}$, while carbofuran was applied at the rate of $3.0 \mathrm{~kg} \cdot \mathrm{ha}^{-1}$. Four weeks old tomato seedlings cultivar 'Roma VF', which is susceptible to RKN, was transplanted to already prepared soil. Results of the experiment showed that the compost, especially in the amount $2 \mathrm{t} \cdot \mathrm{ha}^{-1}$ and carbofuran at $3 \mathrm{~kg} \cdot \mathrm{ha}^{-1}$, brought about significant reduction of the population of RKN in soil and roots, and a significant increase in the growth and yield of tomato. The result of the experiment showed that Siam compost can be used for the managing root-knot nematodes in tomato cultivation, as an environmentally safe factor.
\end{abstract}

Key words: root-knot nematode, compost manure, carbofuran, tomato, growth and yield

\section{INTRODUCTION}

Tomato (Solanum lycopersicum L.) is an important vegetable crop in the world. It is also cultivated throughout tropical Africa (Lester \& Seck 2002). Tomatoes produced in the study area have grossly inadequate growing conditions due to biotic factors adverse to the crop and they do not achieve potential yield. In Nigeria, tomato average yield is $10 \mathrm{t} \cdot \mathrm{ha}^{-1}$ (Dantata et al. 2011), which is lower than the world average of $22 \mathrm{t} \cdot \mathrm{ha}^{-1}$ (Ojeniyi et al. 2007). Yield losses of heavily infected tomato crops can reach up to $80 \%$ (Bourne et al. 2004; Kaşkavalc1 2007). Nematodes can make plants more susceptible to damage by plant pathogenic fungi, bacteria and viruses, which increases the losses of the yield (Rivera \& Abally 2008). Feeding activities of the root-knot nematodes (RKN) in the root tissue result in the formation of massive galls of different sizes on root system. Severally affected plants often wilt readily and may also exhibit nutrient deficiency symptoms because galled roots have limited capacity to absorb and translocate nutrient and water to other plant part (Coyne et al. 2007). An attack of nematodes on crop usually brings about yield reduction. Nematode contributes substantially to hunger all over the world especially in the tropics. They rob man of his fruit of labor (Egunjobi 2014). The rootknot nematode are the most notorious phytophagous nematode (Meloidogyne spp.), since they infest majority of the most important economic plant species in the world. This genus contains over 80 species (Karseen 2002) and has been reported to cause an estimated $\$ 100$ billion loss annually worldwide (Oka 2010). It is therefore expedient to manage $\mathrm{RKN}$ so as to reduce the yield losses in tomato. 
Management of RKN with synthetic nematicides can be very effective. Adegbite and Agbaje (2007) and Dubey and Trivedi (2011) reported a significant reduction in the incidence of Meloidogyne incognita (Kofoid \& White 1919) in three hybrid yam cultivars after an application of carbofuran $3 \mathrm{G}$ at $100 \mathrm{~kg} \cdot \mathrm{ha}^{-1}$. However, scarcity, high cost, environmental safety and global restriction on the importation of chemical nematicides have encouraged scientists to search for alternative control solutions against economically important nematodes (IFCS 2004). Today, the world is becoming more aware of the environmental hazard posed by all synthetic pesticides. Even in advanced countries, where this synthetics are produced and farmers have sufficient skill for application, they are now being replaced with other, more environmentally friendly methods of pest and disease control to minimized environmental pollution and health hazard (Olabiyi 2005). Siam weed is among the most common plants growing as weed in the tropics. Several researchers have consistently reported that some weeds are effective in suppressing nematode population when used as plant extract, organic amendment and recently as cover crop (Adekunle \& Fawole 2003; Adekunle 2011). Organic manure, when incorporated into the soil in large amount, reduces of soil inhabiting pests and pathogens (Abolusoro et al. 2013; 2014). The use of compost manure in crop production when fully developed and integrated can enhance safe food production, minimize environmental hazards and increase acceptability of our products in the European markets.

The objective of this paper is therefore to evaluate the efficacy of Chromolaena odorata compost on root-knot nematode ( $M$. incognita) in tomato crop.

\section{MATERIALS AND METHODS}

\section{Preparation of compost material}

Siam weed (C. odorata) compost was prepared at Landmark University Omu-Aran, Kwara State at the Teaching and Research Farm. Freshly harvested Siam weed was shredded into smaller pieces. $100 \mathrm{~kg}$ of chopped leaves was mixed thoroughly with $15 \mathrm{~kg}$ of poultry manure gotten from deep litter poultry house and wrapped with plastic, properly covered for a period of six month prior to the beginning of the research work - windrone method (Olabiyi et al. 2013). The mixture was properly turned at an interval of one month with garden spade. The fully decomposed materials (compost) were spread, air dried and ground into powder form (Olabiyi et al. 2013).

\section{Field experiment}

A field trail was conducted in a plot naturally infested with M. incognita in the year 2017 and repeated at the same period in the 2018 at the site located in the experimental field of $267.3 \mathrm{~m}^{2}(15.5 \times$ $22.8 \mathrm{~m}$ ). This piece of land was divided into 4 blocks of a size of $13.5 \mathrm{~m}^{2}$. Each block was divided into 5 plots. The experiment was a randomized complete block design comprising of 5 treatments (control, 0.5, 1.0, $2.0 \mathrm{t} \cdot \mathrm{ha}^{-1}$ of compost and carbofuran $3.0 \mathrm{~kg} \cdot \mathrm{ha}^{-1}$ ), replicated 4 times. The organic amendments and carbofuran were added to the plots one week before transplanting.

Tomato seedlings 'Roma VF' were transplanted four weeks after sowing in the nursery to the field at a spacing of $0.4 \mathrm{~m}$ on the ridges. The plants were watered by sprinkler irrigation and manually weeding was carried out fortnightly in each year of the experiment. The trial for each year was terminated one hundred and fifty days after planting.

\section{Soil and nematode}

Soil samples for nematode analysis were collected separately from every experimental plot before planting and after harvest. Soil was collected with soil auger very close to the base of the tomato plant and mixed thoroughly. Nematodes were extracted from $200 \mathrm{ml}$ sub-samples using the method described by Whitehead and Hemming (1965). The species of the RKN was identified by perineal pattern of structure of females using the method described by Eisenback et al. (1981).

At the end of the study, the tomato plants were carefully dug up and assessed for galling, according to the method described by Taylor and Sasser (1978): $0=$ no galls; $1=1-2$ galls; $2=3-10$ galls; $3=11-$ 30 galls; $4=31-100$ galls; $5=$ more than 100 galls.

At planting, the soil nematode population was between 2105-2111 second stage juvenile (J2) in $200 \mathrm{ml}$ soil in 2017 and 2092-2101 J2 in $200 \mathrm{ml}$ soil in 2018. 


\section{Data analysis}

All numerical data collected were subjected to analysis of variance. The significance of differences between means was evaluated using Duncan's Multiple Range Test at 5\% level of probability.

\section{RESULTS}

\section{Growth of tomato in the soil infested with root-} knot nematode

Plants grown on plots with higher quantity of Siam compost or carbofuran recorded significant differences in the height and leaf number compared with lower dose of compost treatment and untreated control. In both years (2017 and 2018), there were no significant differences between carbofuran and Siam compost at $2 \mathrm{t} \cdot \mathrm{ha}^{-1}$ for plant height, whereas the lowest compost dose did not differ from the control. Number of leaves per plant was significantly lowest in control and in the treatments grown in the highest compost doses and in carbofuran treatment (Table 1).

Flowering of tomato grown in the soil infested with root-knot nematode

There were significant differences in the number of days to $50 \%$ flowering and number of flowers between different levels of compost and carbofuran application. Plants that received the highest dosage of compost $\left(2 \mathrm{t} \cdot \mathrm{ha}^{-1}\right)$ or carbofuran bloomed in shorter time and had more flowers compared to the lower dosage (1.0 and $\left.0.5 \mathrm{t} \cdot \mathrm{ha}^{-1}\right)$ and the control. This observation was consistent for the two years of experimentation (Table 2).

Yield components of tomato grown in the soil infested with root-knot nematode

The fruit number per plant was three times lower in control then at the highest dose of Siam compost and carbofuran, whereas fruit yield per plant increased at the same pattern but the difference was five times (Table 3).

\section{Population of root-knot nematode in the tomato roots and in the soil}

The highest population of root-knot nematode was recorded in soil and plant roots grown without any protection (Table 4). Number of nematodes in the roots was three times higher in control than in carbofuran treatment in 2017 and five times higher in 2018. These numbers decreased significantly with increasing Siam compost doses. The soil nematode decreased in the same pattern and differences between control and carbofuran treatment were doubled. Root gall indices were twice higher in the control than in carbofuran treatment. In all cases, the highest dose of Siam compost was most effective but significantly lower than in the carbofuran treatment.

Table 1. Effect of Siam compost $\left(\mathrm{t} \cdot \mathrm{ha}^{-1}\right)$ and carbofuran $\left(3 \mathrm{~kg} \cdot \mathrm{ha}^{-1}\right)$ on the growth of tomato in the soil infested with root-knot nematodes

\begin{tabular}{ccccc}
\hline & \multicolumn{2}{c}{2017} & \multicolumn{2}{c}{2018} \\
\cline { 2 - 5 } Treatment & $\begin{array}{c}\text { Average plant height } \\
(\mathrm{cm})\end{array}$ & $\begin{array}{c}\text { Average leaf number } \\
\text { per plant }\end{array}$ & $\begin{array}{c}\text { Average plant height } \\
(\mathrm{cm})\end{array}$ & $\begin{array}{c}\text { Average leaf number } \\
\text { per plant }\end{array}$ \\
\hline Control & $66.9^{\mathrm{c}} \pm 0.05$ & $27.1^{\mathrm{e}} \pm 0.06$ & $68.3^{\mathrm{b}} \pm 0.10$ & $28.81^{\mathrm{e}} \pm 0.11$ \\
0.5 & $66.9^{\mathrm{c}} \pm 0.02$ & $40.45^{\mathrm{d}} \pm 0.05$ & $68.5^{\mathrm{b}} \pm 0.10$ & $40.35^{\mathrm{d}} \pm 0.11$ \\
1.0 & $73.6^{\mathrm{b}} \pm 0.01$ & $42.95^{\mathrm{c}} \pm 0.06$ & $75.8^{\mathrm{a}} \pm 0.21$ & $42.23^{\mathrm{c}} \pm 0.12$ \\
2.0 & $75.4^{\mathrm{a}} \pm 0.01$ & $44.86^{\mathrm{b}} \pm 0.06$ & $75.8^{\mathrm{a}} \pm 0.22$ & $43.93^{\mathrm{b}} \pm 0.11$ \\
Carbofuran & $75.7^{\mathrm{a}} \pm 0.02$ & $45.00^{\mathrm{a}} \pm 0.06$ & $76.1^{\mathrm{a}} \pm 0.21$ & $45.97^{\mathrm{a}} \pm 0.12$ \\
\hline p value & 0.000 & 0.000 & 0.000 & 0.000 \\
\hline
\end{tabular}

Each value is a mean \pm SE of the four replicates. Means followed by the same letter are not significantly different at $p<0.05$ according DMRT. 
Table 2. Effect of Siam compost $\left(\mathrm{t} \cdot \mathrm{ha}^{-1}\right)$ and carbofuran $\left(3 \mathrm{~kg} \cdot \mathrm{ha}^{-1}\right)$ on the flowering of tomato growing in the soil infested with root-knot nematode

\begin{tabular}{ccccc}
\hline \multirow{2}{*}{ Treatment } & \multicolumn{2}{c}{2017} & \multicolumn{2}{c}{2018} \\
\cline { 2 - 5 } & $\begin{array}{c}\text { Mean number of days to } \\
50 \% \text { flowering }\end{array}$ & $\begin{array}{c}\text { Average number of } \\
\text { flowers per plant }\end{array}$ & $\begin{array}{c}\text { Mean number of days } \\
50 \% \text { flowering }\end{array}$ & $\begin{array}{c}\text { Average number of } \\
\text { flowers per plant }\end{array}$ \\
\hline Control & $66.70^{\mathrm{a}} \pm 1.31$ & $7.27^{\mathrm{e}} \pm 1.11$ & $67.50^{\mathrm{a}} \pm 1.30$ & $9.52^{\mathrm{e}} \pm 0.11$ \\
0.5 & $62.58^{\mathrm{b}} \pm 1.20$ & $20.23^{\mathrm{d}} \pm 1.51$ & $63.10^{\mathrm{b}} \pm 1.41$ & $21.35^{\mathrm{d}} \pm 1.25$ \\
1.0 & $60.10^{\mathrm{c}} \pm 1.31$ & $28.28^{\mathrm{c}} \pm 1.20$ & $60.38^{\mathrm{c}} \pm 1.32$ & $28.60^{\mathrm{c}} \pm 1.34$ \\
2.0 & $56.23^{\mathrm{d}} \pm 1.24$ & $40.76^{\mathrm{b}} \pm 1.21$ & $55.00^{\mathrm{d}} \pm 1.33$ & $36.37^{\mathrm{b}} \pm 1.61$ \\
carbofuran & $53.10^{\mathrm{e}} \pm 1.21$ & $46.20^{\mathrm{a}} \pm 1.56$ & $57.20^{\mathrm{e}} \pm 1.10$ & $45.33^{\mathrm{a}} \pm 1.43$ \\
\hline p value & 0.000 & 0.000 & 0.000 & 0.000 \\
\hline
\end{tabular}

Note: See Table 1

Table 3. Effect of Siam compost $\left(\mathrm{t} \cdot \mathrm{ha}^{-1}\right)$ and carbofuran $\left(3 \mathrm{~kg} \cdot \mathrm{ha}^{-1}\right)$ on yield components of tomato growing in the soil infested with root-knot nematode

\begin{tabular}{ccccc}
\hline \multirow{2}{*}{ Treatment } & \multicolumn{2}{c}{2017} & \multicolumn{2}{c}{2018} \\
\cline { 2 - 5 } & $\begin{array}{c}\text { Average number } \\
\text { of fruits per plant }\end{array}$ & $\begin{array}{c}\text { Average fruit yield } \\
\text { per plant }(\mathrm{g})\end{array}$ & $\begin{array}{c}\text { Average number } \\
\text { of fruits per plant }\end{array}$ & $\begin{array}{c}\text { Average fruit yield } \\
\text { per plant }(\mathrm{g})\end{array}$ \\
\hline Control & $6.71^{\mathrm{e}} \pm 1.20$ & $98.1^{\mathrm{e}} \pm 2.11$ & $6.94^{\mathrm{e}} \pm 1.12$ & $102.1^{\mathrm{e}} \pm 2.45$ \\
0.5 & $15.74^{\mathrm{d}} \pm 1.41$ & $369.7^{\mathrm{d}} \pm 2.40$ & $16.01^{\mathrm{d}} \pm 1.20$ & $368.0^{\mathrm{d}} \pm 2.34$ \\
1.0 & $17.22^{\mathrm{c}} \pm 1.32$ & $407.7^{\mathrm{c}} \pm 2.41$ & $17.30^{\mathrm{c}} \pm 1.23$ & $400.3^{\mathrm{c}} \pm 2.21$ \\
2.0 & $19.96^{\mathrm{b}} \pm 1.31$ & $485.3^{\mathrm{b}} \pm 2.36$ & $19.40^{\mathrm{b}} \pm 1.11$ & $479.7^{\mathrm{b}} \pm 2.12$ \\
carbofuran & $21.47^{\mathrm{a}} \pm 1.42$ & $502.3^{\mathrm{a}} \pm 2.54$ & $20.90^{\mathrm{a}} \pm 1.13$ & $500.2^{\mathrm{a}} \pm 2.11$ \\
\hline p value & 0.000 & 0.000 & 0.000 & 0.000 \\
\hline
\end{tabular}

Note: See Table 1

Table 4: Effect of Siam compost $\left(\mathrm{t} \cdot \mathrm{ha}^{-1}\right)$ and carbofuran $\left(3 \mathrm{~kg} \cdot \mathrm{ha}^{-1}\right)$ on the root and soil population of nematode as well as gall index of tomato growing in the soil infested with root-knot nematode

\begin{tabular}{|c|c|c|c|c|c|c|}
\hline \multirow[b]{2}{*}{ Treatment } & \multicolumn{3}{|c|}{2017} & \multicolumn{3}{|c|}{2018} \\
\hline & $\begin{array}{c}\text { Number of } \\
\text { nematodes in } \\
5 \mathrm{~g} \text { root }\end{array}$ & $\begin{array}{l}\text { Soil nematode } \\
\text { population in } \\
200 \mathrm{ml} \text { soil } \\
\end{array}$ & $\begin{array}{l}\text { Root gall in- } \\
\text { dex }\end{array}$ & $\begin{array}{c}\text { Number of nem- } \\
\text { atodes in } 5 \mathrm{~g} \\
\text { root }\end{array}$ & $\begin{array}{c}\text { Soil nematode } \\
\text { population in } 200 \\
\text { ml soil }\end{array}$ & Root gall index \\
\hline Control & $15.90^{\mathrm{a}} \pm 0.12$ & $870.40^{\mathrm{a}} \pm 3.20$ & $4.15^{\mathrm{a}} \pm 0.01$ & $27.73^{\mathrm{a}} \pm 0.41$ & $865.48^{a} \pm 2.65$ & $4.35^{\mathrm{a}} \pm 0.01$ \\
\hline 0.5 & $12.87^{b} \pm 0.22$ & $648.46^{b} \pm 3.12$ & $2.85 b \pm 0.01$ & $14.10^{\mathrm{b}} \pm 0.35$ & $649.82^{\mathrm{b}} \pm 2.14$ & $2.83^{b} \pm 0.02$ \\
\hline 1.0 & $12.23^{\mathrm{c}} \pm 0.20$ & $553.87^{c} \pm 3.10$ & $2.77^{\mathrm{c}} \pm 0.02$ & $12.60^{c} \pm 0.31$ & $544.28^{c} \pm 2.11$ & $2.67^{c} \pm 0.02$ \\
\hline 2.0 & $7.40^{\mathrm{d}} \pm 0.13$ & $473.50^{\mathrm{d}} \pm 2.88$ & $2.37^{\mathrm{d}} \pm 0.01$ & $7.773^{\mathrm{d}} \pm 0.21$ & $493.20^{\mathrm{d}} \pm 2.12$ & $2.34^{\mathrm{d}} \pm 0.02$ \\
\hline carbofuran & $5.40^{\mathrm{e}} \pm 0.13$ & $421.60^{\mathrm{e}} \pm 2.56$ & $1.90^{\mathrm{e}} \pm 0.01$ & $5.66^{\mathrm{e}} \pm 0.21$ & $454.60^{\mathrm{e}} \pm 2.01$ & $1.80^{\mathrm{e}} \pm 0.01$ \\
\hline $\mathrm{p}$ value & 0.000 & 0.000 & 0.000 & 0.000 & 0.000 & 0.000 \\
\hline
\end{tabular}

Note: See Table 1 


\section{DISCUSSION}

Addition of Siam compost or carbofuran to nematode infested soil reduced the population density of $M$. incognita and increased the growth and fruit yield of tomato. The nature of plant protection against nematodes by Siam weed compost can be connected with the ability to stimulate multiplication of micro-organisms like fungi and bacteria, some of which are antagonists or parasites of nematodes causing the reduction of nematodes population, thereby promoting growth and development of tomato (Ali et al. 2017). Timper (2014) reported that organic manure, including compost amended to the soil, improves the performance of nematode infested plant due to direct stimulation of predators and parasites of nematodes leading to reduction in soil pathogens and consequent increase in growth and yield. Similar results were obtained by Chindo and Khan (1990) who reported significant reduction of nematode population on S. lycopersicum with increase in growth, yield and reduced gall index of root-knot nematode due to treatment with organic manure compared to the untreated control.

Another reason of better growth of plants in soil with compost addition might be a general improvement in the soil fertility as well as the nemato-toxic substances released by the compost manure on decomposition (Riegel \& Noe 2000; Oka 2010). These toxins may have reduced the number of juvenile forms of $M$. incognita by killing them. Organic manure including compost has been shown to be rich in nitrogen and phenolic compounds (Agyarko et al. 2006; Renčo \& Kováčik 2012). On decomposition, nitrogen is converted to ammonia (Lazarovits et al. 2001; Oka 2010), which can be toxic to several soil nematode species (Lazarovits et al. 2001). Phenolic compounds are also reported to be lethal to plant parasitic nematodes (Nwanguma \& Fawole 2004).

In our experiment, the heavily galled roots and reduced yield of tomato in the control treatment indicates that tomato 'Roma VF' used in the study is susceptible to M. incognita. The result of this study proved that the application of Siam weed compost can be successfully used for controlling root-knot nematode as replacement for human toxic, environmentally unfriendly, costly and not recommended or prohibited synthetic chemicals for managing root-knot nematode affecting our economic crops.

\section{CONCLUSION}

The result from this research showed that Siam weed compost has nematicidal properties, especially when applied at the dose of $2 \mathrm{t} \cdot \mathrm{ha}^{-1}$; hence, can be used in the management of plant root-knot nematodes. To confirm the presented research, we are still conducting experiments on the possibility of using higher doses of Siam compost, changes in the reaction of plants and nematodes depending on the formulation of compost to select the dose most effective and economically justified.

\section{REFERENCES}

Abolusoro S.A., Abe M.O., Abolusoro P.F., Izuogu N.B. 2013. Control of nematode disease of eggplant ( $\mathrm{So}$ lanum aethiopicum $\mathrm{L}$.) using manure. Agriculturae Conspectus Scientificus 78(4): 327-330.

Abolusoro P.F., Ogunjimi S.I., Abolusoro S.A. 2014. Farmers' perception on the strategies for increasing tomato production in Kabba-Bunu Local Government Area of Kogi-State, Nigeria. Agrosearch 14(2): 144-153. DOI: 10.4314/agrosh.v14i2.5.

Adegbite A.A., Agbaje G.O. 2007. Efficacy of Furadan (carbofuran) in control of root-knot nematode (Meloidogyne incognita race 2) in hybrid yam varieties in south-western Nigeria. World Journal of Agricultural Sciences 3(2): 256-262.

Adekunle O.K., Fawole B. 2003. Comparison of effects of extracts of siam weed, neem and carbofuran on generation time and reproduction of Meloidogyne incognita race 2 on tomato. Environment and Ecology 21: 720-726.

Adekunle O.K. 2011. Amendment of soil with African marigold and sunn hemp for management of Meloidogyne incognita in selected legumes. Crop Protection 30: 1392-1395. DOI: 10.1016/j.cropro.2011.07.007.

Agyarko K., Kwakye P.K., Bonsu M., Osei B.A., Frimpong K.A. 2006. The effect of organic soil amendments on root-knot nematodes, soil nutrients and growth of carrot. Journal of Agronomy 5: 641646. DOI: 10.3923/ja.2006.641.646.

Ali M.A., Azeem F., Abbas A., Joyla F.A., Li H., Dababat AA. 2017. Transgenic strategies for enhancement of nematode resistance in plants. Frontiers in Plant Science $8 ; 750 ; 13$ p. DOI: 10.3389/fpls.2017.00750.

Bourne J.M., Karanja P.K., Kalisz H., Karanja D.K., Mauchline T.H., Kerry B.R. 2004. Incidence and severity of damage caused by Meloidogyne spp. 
and isolation and screening of the nematophagous fungus Pochonia chlamydosporia from some of the main vegetable growing areas in Kenya. International Journal of Nematology 14: 111-120.

Chindo P.S., Khan F.A. 1990. Control of root-knot nematodes, Meloidogyne spp., on tomato, Lycopersicon esculentum Mill., with poultry manure. Tropical Pest Management 36: 332-335. DOI: 10.1080/09670879009371504.

Coyne D.L., Nicol J.M., Claudius-Cole B. 2007. Practical plant nematology: A field and laboratory guide, 2nd ed. SP-IPM, International Institute of Tropical Agriculture, Cotonou, Benin, 82 p.

Dubey W., Trivedi P.C. 2011. Evaluation of some nematicides for the control of Meloidogyne incognita of okra. Indian Journal of Fundamental and Applied Life Sciences 1: 264-270.

Dantata I.J., Kapsiya J., Ibrahim M.M. 2011. Growth and yield of tomato in response to application of different organic manures on an Alfisol. Proceedings of the 35th Annual Conference of the Soil Science Society of Nigeria, 7-11 March 2011, Federal University of Technology, Minna, Nigeria, pp. 101-108.

Egunjobi A.O. 2014. Nematode and Man's Welfare. 2nd National Conference of the Nigerian Society of Nematologists, November 2014, University of Ibadan, Ibadan, Nigeria, pp. 5-8.

Eisenback J.D., Hirschmann H., Sasser J.N., Triantaphyllou A.C. 1981. A guide for the four most common species of root-knot nematodes (Meloidogyne spp.), with a pictorial key. International Meloidogyne Project, Raleigh, USA, 48 p.

IFCS 2004. Intergovernmental Forum on Chemical Safety. Information Circular. Pesticide and Alternative 23: 2-3.

Karssen G. 2002. The plant-parasitic nematode genus Meloidogyne Göldi, 1892 (Tylenchida) in Europe. Koninklijke Brill, Leiden, the Netherlands, 157 p.

Kaşkavalcı G. 2007. Effects of soil solarization and organic amendment treatments for controlling Meloidogyne incognita in tomato cultivars in western Anatolia. Turkish Journal of Agriculture and Forestry 31: 159-167.

Lazarovits G., Tenuta M., Conn K.L. 2001. Organic amendments as a disease control strategy for soilborne diseases of high-value agricultural crops. Australasian Plant Pathology 111-117. DOI: 10.1071/ap01009.
Lester R.N., Seck A. 2002. Solanum aethiopicum L. In: Oyen L.P.A, Lemmens R.H.M.J. (Eds.), Plant Resources of Tropical Africa. Precursor. PROTA Programme, the Netherlands, pp. 131-134.

Nwanguma E.I., Fawole B. 2004. Efficacy of organic soil amendments on the population of $M$. incognita on okra in South Western Nigeria. Nigerian Journal of Horticultural Science 9(1): 89-95. DOI: 10.4314/njhs.v9i1.3385.

Oka Y. 2010 Mechanism of nematode suppression by organic soil amendments - A review. Applied Soil Ecology 44: 101-115. DOI: 10.1016/j.apsoil.2009.11.003.

Olabiyi T.I., Atungwu J.J., Izuogu B., Akintola J., Abolusoro S. 2013 Efficacy of neem compost on root knot nematode of Lagos spinach, Celosia argentea. Archives of Phytopathology and Plant Protection 46: 2253-2258. DOI: 10.1080/03235408.2013.792536.

Olabiyi T.I. 2005. Effect of African marigold extracts (Tagetes erecta L.) on root-knot nematode infecting okra (Abelmoschus esculentus (L.) Moench). Science Focus 10: 47-51.

Ojeniyi S.O., Awodun M.A., Odedina S.A. 2007. Effect of animal manure amended spent grain and cocoa husk on nutrient status, growth and yield of tomato. Middle-East Journal of Scientific Research 2(1): 33-36.

Renčo M., Kováčik P. 2012. Response of plant parasitic and free living soil nematodes to composted animal manure soil amendments. Journal of Nematology 44: 329-336.

Riegel C., Noe J.P. 2000. Chicken litter soil amendment effects on soilborne microbes and Meloidogyne incognita on cotton. Plant Disease 84: 1275-1281. DOI: $10.1094 /$ pdis.2000.84.12.1275.

Rivera L., Aballay E. 2008. Nematicide effect of various organic soil amendments on Meloidogyne ethiopica Whitehead, 1968, on potted vine plants. Chilean Journal of Agricultural Research 68(3): 290-296. DOI: $10.4067 / \mathrm{s} 0718-58392008000300009$.

Taylor A., Sasser J.N. 1978. Biology identification and control of root-knot nematodes Meloidogyne spp. North Carolina State University, Raleigh, USA, 111 p.

Timper P. 2014. Conserving and enhancing biological control of nematodes. Journal of Nematology 46(2): 75-89.

Whitehead A.G., Hemming J.R. 1965. A comparison of some quantitative method of extracting vermiform nematodes from soil. Annals of Applied Biology 55: 25-38. DOI: 10.1111/j.1744-7348.1965.tb07864.x. 